\title{
ADDITIVES USED IN EXTENDERS TO IMPROVE THE FREEZABILITY OF RAM SEMEN IN RECENT YEARS: a mini review
}

\section{Y. ÖZTÜRKLER, U.Ç. ARI}

Department of Reproduction \& Artificial Insemination, Clinical Sciences Section, Veterinary Faculty, Kafkas University, 36000, Kars, Turkey, e-mail yavuzozturkler@hotmail.com (corresponding author);

The authors declare no conflict of interests

Received December 30, 2016

\section{Abstract}

One of the most important reasons why artificial insemination does not spread as much in cattle as sheep is that ram sperm is highly fragile against cryodamage and consequently the optimum fertility results can not be obtained from cervical inseminations compared to laparoscopic insemination. To establish an ideal ram sperm freezing model, many studies have been carried out for more than 60 years and various methods have been tested by making great efforts. One of the topics where these tests have been done intensively in recent years are additives used in freezing extenders in order to increase the tolerance of sperm against oxidative stress in frozen-thawed ram semen. In this review, covering the studies carried out between the years 2000-2016, we have mostly compiled the additives used in ram semen freezing media which have given better results compared to others supplements. It is understood that, usually, seminal plasma and proteins, thiol compounds, enzymatic antioxidants, sugars, fatty acids and vitamins have been studied as additive agents in recent years. As a result, this review suggests us that further studies are needed to explore the novel techniques and new additives, and their combinations should be tested in different doses in order to install an ideal cryopreservation template for ram semen. Furthermore, even though addition of various compounds to freezing media have improved freezability of ram semen in experimental conditions, anyway these results must be confirmed in field studies. Therefore, the value of sperm which potential fertility is predicted from laboratory survey must be compared with conception or lambing rates.

Keywords: ram semen, additives, freezability, extender

While the basic techniques related to sperm freezing have done positive effects and important advances mostly on dairy cattle husbandry, any remarkable success has not been provided in sheep. Substantially, these matter is caused mainly by from two reasons following as: i] intolerance of ram sperm against cryopreservation, ii] the physiological and anatomic factors in sperm transport. It is well known subject for a long time that freezing and thawing of ram sperm have caused significant membran and genetic damage [1]. As cervical insemination has given poor fertility results compared to laparascopic inseminations, artificial insemination with frozen semen has not become widespread in sheep husbandry [2]. On the other hand, the expenses of ram semen freezing are almost 20 times more than those of bull semen freezing cost [3]. B Recently, investigators have focused mostly on especially composition, determination of in vivo properties and effects of different cryoprotectants, antioxidants and specific supplements in sperm freezing [4].

We understood from literature documented here, no comprehensive review of the researches on frozen ram sperm has been found from that date into the past 16 years. During 2000s, the attentions of researchers have mostly concentrated on additives for improving membrane repair and increasing progressive motility in ram semen cryopreservation. It seems that while base extenders used in ram semen freezing has not been much changed, many various supplements has been tested from the beginning of 2000's to now. 
However, in this review, only additives that often have improving effects on frozen-thawed ram semen are mentioned. The additives studied between 20002016 years are reviewed here and considerations has presented below.

Seminal plasma and its protein components (SPPs). The role of seminal plasma in reproductive technologies such as sperm freezing and sex determination is already proven and it is also agreed that seminal plasma addition to ram semen freezing medium had a improving effects on post-thaw motlitity and morphological damage [5, 6]. Furthermore, although seminal plasma proteins show protective effect in freezing and thawing processes of ram semen, interestingly the same effect has not been in bull semen [7].

When seminal plasma proteins are used alone or combined with other compounds such as oleic/linoleic acids and vitamin E etc., the protective effect is not only observed in fresh sperm but also after freezing and thawing, so that SPPs provide regular regenerative SOD distribution by using combined with oleic / linoleic acids and vitamin E [6]. However, still, more investigations are necessary to solving of biological complicacies, and then identify and synthesize favorable proteins within seminal plasma [8].

Antioxidants. As sperm membrane contains higher of unsaturated fatty acids than those of somatic cells, it is inclinable to oxidative stress, thus plasma and mitochondrial membrane is highly susceptible against cold shock. Moreover, sperm has not is any restoration mechanism in prevent cell injuries caused by ROS. The antioxidants which are mainly present in seminal plasma in semen have limited protective effect $[9,10]$. Moreover, antioxidants are used not only for protecting of membrane integrity of sperm cell, but also, the membrane damage of embryo and oocytes by depressing of lipid peroxidation and ROS production [11].

Thiol compounds. It has been known that thiol compounds have an scavenger effect for elimination of cytoxins and ROS which give cellular defects caused by ROS [12]. In recent years, thiol compunds such as 1-erhothioneine [LE], Cystein and N-aceytyl cysteine have been frequently studied. It has been observed that thiol compounds have given the improving effect of ram semen freezability [13-18].

Cystein. Cystein is also one of thiol compunds which protects against oxidative stress damage of ram sperm cell during cryopreservation processes. The addition of cysteine to ram semen freezing medium has provided high motility rates and catalase level [14].

$N$-acetyl cystein [NAC]. NAC which is a precursor of intracellular GSH biosynthesis, has been rarely studied by researchers in ram semen freezing $[17,18]$.

Enzymatic antioxidants. Enzymatic antioxidants protect cells prevent from cellular membrane damage with neutralizing ROS produced by cellular components. Enzymatic antioxidants contain superoxide dismutase [SOD], catalase, glutathione peroxidase [GPx], and glutathione reductase [GR] [19].

Some researchers have claimed that the supplementations of catalase [20], SH-glutathione [GSH], SOD [21, 22], Gpx and Tempo or Tempol [as SOD mimics] [23] have improved in semen quality in frozen-thawed samples.

Non-enzymatic antioxidants and sugars (trehalose and sucrose). Synthetic antioxidants or food supplements such as vitamins, and minerals, $B S A$ [bovine serum albumin, trehalose, vitamin $\mathrm{C}$, vitamin $\mathrm{E}$, zinc, cysteine, taurine, hypotaurine, and lutathione etc. has been accepted as non-enzymatic antioxidants [19 According to the results of some studies, BSA, cysteine, lycopene [24], trehalose, taurine, cysteamine, hyaluronan [24] and combination of sucrose and trehalose combination [25] in freezing diluents have given satisfacto- 
ry percentages of motility, viability and acrosomal membrane integrity.

Lecithin. Despite mechanism of action of lecithin on sperm plasma stabilization during freezing and thawing is not clearly know, it has been reported that lecithin and other lipidic supplements protect and stabilize the sperm membrane by substation of phospholipids, thereby increasing resistance to freezing. Some studies demonstrate that use, alone or combined with some compounds, of $1.5 \%$ soya bean lecithin has given better spermatological values motility, viability and intact membrane compared to hyaluronic acid (HA) [26] and egg yolk [27] additions, and also could be alternative a cryoprotectant aid instead of egg yolk [28]. Although egg yolk has been found as superior to lecithin in a study [29], when compared to in another study, it has been reported that lecithin could be used instead of egg yolk. In Bakhtiari rams, spermatological results obtained from the diluents which included $1 \%$ lecithin, $20 \%$ egg yolk and $7 \%$ glycerol were superior in the freezing process and it was concluded that lecithin could be used instead of egg yolk [30].

Fatty acids $(F A)$. Long-chain polyunsaturated fatty acids (LCP-UFA) of the n-3 series provide suitable stabilization by maintaining of liquidity and elasticity of cell membran, thus, supplementation of (polyunsaturated fatty acids) (PUFA) increase the sperm cell number, motility and sperm fertilizing potential by strengthening against lipid peroxidation in mamals [31)].

Fatty acids, such as oleic acid, linoelic acids, n-3 ( $\omega-3)$ FA have been used by investigators in order to support the sperm against oxidative stress damage and obtain an optimum cryosurvival in frozen-thawed semen. It has been alleged that the combination of oleic/linoleic acids with vitamin E and SPPs (6), some other agents, e.g. fatty acid amide hydrolase (FAAH) [32], and $\omega-3$ FA provided protection in frozen-thawed ram sperm.

Vitamins. Currently, it has been understood that the vitamin E [31, 33], vitamin $C$ [34-38] and vitamin $B_{12}[39,40]$ additions to semen freezing diluents have enhanced the spermatological properties by eliminating of ROS damage to sperm cells.

Hormones. It has reported that there is a relationship between hormones and sperm damage [41, 42]. From articles scanned here, no study was not seen which has been searched the directly addition of hormones to ram semen freezing extenders except for one study which established the effect of melatonin hormone. In this study, $1 \mathrm{mM}$ melatonin additions were found to be quite successful in terms of total and progressive motility, intracellular ATP concentrations and DNA integrity, especially in viability rates. In addition, in vitro embryonic development was highest in the group with $1 \mathrm{mM}$ melatonin [43].

Other substances. Some alternative substances have been tested, as alone or combined by, with/without various glycerol concentrations in extenders for improving freezability of ram semen [33, 44, 45].

One of surfactant detergents, Equex, is known that stabilizes the cell membrane, protects from cellular toxication and membrane damage after freezing and thawing semen. With respect to results of a research the addition of $0.75 \%$ Equex STM ${ }^{\circledR}$ yielded better spermatological percentages (motility, viability, membrane integrity) and DNA fragmentation compared to control samples. Moreover, in two trials comparing methyl formamide (MF) and ethylene glycol (EG) with glycerol $(\mathrm{G})$ it has been observed that glycerol gave more cryosurvival quality [44] than MF and EG additions [33], however, the nearest results to glycerol $(5 \%)$ were provided in the sample concentrated with EG $3 \%$ (Table). On the other hand, the addition of $3 \%$ glycerol ve $1.5 \mathrm{mg} \mathrm{CLC} / 120 \times 10^{6}$ spermatozoa combination to freezing diluent was more amendatory compared to other groups, despite glycerol decreased the viability [45]. 
Various additives used for cryopreservation of ram semen and reported frozenthawed spermatological quality

\begin{tabular}{|c|c|c|c|c|c|c|c|c|c|}
\hline \multirow{2}{*}{ Research } & \multirow{2}{*}{ Base extender } & \multirow{2}{*}{ Additives } & \multirow{2}{*}{ Quantity } & \multicolumn{2}{|c|}{ Motility } & \multicolumn{4}{|c|}{ Percentage } \\
\hline & & & & 1 & 2 & 3 & 4 & 5 & 6 \\
\hline Aisen et al., 2002 & TCFY10+G $\underline{3}$ & Trehalose & $100 \mathrm{mM}$ & 65 & & & & 50 & \\
\hline Baran et al., 2004 & $\mathrm{TCGz}$ & SP & $7.5 \%$ & 30 & & & $56 \mathrm{AA}$ & & 56 \\
\hline \multirow[t]{4}{*}{ Uysal et al., 2007} & TCFY 10 & GSSG & $5 \mathrm{mM}$ & 60 & & 78 & $3 \mathrm{AA}$ & 65 & 10 \\
\hline & TCFY $\underline{10}$ & BSA & $20 \mathrm{mg} / \mathrm{ml}$ & 51 & & 78 & $4 \mathrm{AA}$ & 55 & 12 \\
\hline & TCFY 10 & Cystein & $10 \mathrm{mM}$ & 59 & & 73.5 & $3 \mathrm{AA}$ & 41 & 19.2 \\
\hline & TCFY 10 & Likopen & $800 \mu \mathrm{g}$ & 57.2 & & 70.5 & $7 \mathrm{AA}$ & 49 & 16.3 \\
\hline Bucak et al., 2007 & TCFY 10 & Taurine & $25 \mathrm{mM}$ & 63.0 & & 73.0 & $6 \mathrm{AA}$ & 44,0 & 23.7 \\
\hline Bucak et al., 2008 & TCFY $\underline{10}+\mathrm{G} \underline{5}$ & Cystein & $5 \mathrm{mM}$ & 61.0 & & 27 & $10 \mathrm{AA}$ & 48 & 30 \\
\hline Marti et al., 2008 & $\begin{array}{l}\text { SMY }+\bar{G} 7+\bar{G} \text { alacto } \\
\text { se } 112 \mathrm{MM}\end{array}$ & $\begin{array}{l}\text { +SPP+ol- } \\
\text { lin+vit E }\end{array}$ & $\begin{array}{l}4 \mathrm{mg}+25 \mathrm{mM} \\
+2 \mathrm{mM}\end{array}$ & 48.8 & & 36.3 & & 27,0 & \\
\hline \multirow{2}{*}{ Anghel et al., 2009} & $\mathrm{TCGzY} \underline{20}+\mathrm{G} \underline{5}$ & Cystein & $5 \mathrm{mM}$ & 60 & & 60 & & 60 & 12 \\
\hline & TCGzY & Cystein & $10 \mathrm{mM}$ & 72 & & 70 & & 68 & 17 \\
\hline Uysal et al., 2009 & $\mathrm{TCGzY} \overline{15}+\mathrm{G} \overline{5}$ & Trehalose & $100 \mathrm{mM}$ & 72.0 & & 74.5 & & 66,1 & 28.7 \\
\hline $\begin{array}{l}\text { Forouzanfar et al., } \\
2010\end{array}$ & $\mathrm{TCFY} \underline{20}+\mathrm{G} 7$ & Lechitin & $1 \%$ & 51.9 & & 48.1 & & & \\
\hline Maia et al., 2010 & TGzY & Catalase & $50 \mu \mathrm{g}$ & $69-75$ & $27-30$ & & & & \\
\hline \multirow[t]{2}{*}{ Silva et al., 2011} & TCFY2 & SOL & $100 \mathrm{U} / \mathrm{ml}$ & 58.4 & 9.4 & & 33.5 & & \\
\hline & TCF & GS & $2 \mathrm{mM}$ & 49.45 & 9.19 & & 32 & & \\
\hline Succu et al., 2011 & $\mathrm{TCF}$ & Mel & $1 \mathrm{mN}$ & 45.9 & 31 & 68.7 & & & \\
\hline \multirow[t]{2}{*}{ Silva et al., 2012} & TCFY 20 & Glycerol & $5 \%$ & & 49,2 & & 33.3 & & \\
\hline & TCFY & EG & $3 \%$ & & 41,7 & & 39.8 & & \\
\hline Silva et al., 2012 & TCFY $\underline{20}+\mathrm{G} \underline{5}$ & Vit E & $120 \mu \mathrm{M}$ & 80 & 14 & & 55 & 45 & \\
\hline Ari et al., 2012 & SMEGsY $10+G 5$ & LE & $10 \mathrm{mM}$ & & 23 & 27.1 & 30 & 37.1 & \\
\hline Towhidi et al., 2013 & Andromed & $\begin{array}{l}\text { Vit E+ }+\omega-3- \\
\text { FA }\end{array}$ & $\begin{array}{l}0.1 \mathrm{mM}+ \\
1 \mathrm{ng} / \mathrm{mL}\end{array}$ & 37 & 33 & 35 & & & 3 \\
\hline Das Graça & TCG & MF & $3 \%$ & 38 & & & & & $77 \mathrm{~N}$ \\
\hline 2013 & TCGsY 20 & Glycerol & $5.3 \%$ & 50 & & & & & $84 \mathrm{~N}$ \\
\hline $\begin{array}{l}\text { Motamedi-Mojdehi } \\
\text { et al., } 2014\end{array}$ & $\mathrm{TCFY} \underline{\underline{0}}+\mathrm{G} \underline{3}$ & CLC & $1.5 \mathrm{mg}$ & 45 & & & & 32 & \\
\hline Santiani et al., 2014 & SMFY5+G7 & Tem & $1 \mathrm{~m}$ & 52 & & & 41 & & \\
\hline Šterbenc e & TCFY & Eque & 0. & 78 & 26 & 88 & & 60 & \\
\hline Najafi et al., 2014 & $\mathrm{TCFY} \underline{20}+\mathrm{G} \underline{7}$ & $\mathrm{SL}$ & $1.5 \%$ & 53 & 56 & & & 45 & \\
\hline $\begin{array}{l}\text { Emamverdi et al., } \\
2014\end{array}$ & TY $\underline{20}$ & SL & $1.5 \%$ & 56 & 26 & 39 & & 51 & \\
\hline Mata et al., 2015 & TES-TC & SL & $3.5 \%$ & 52 & & & $28 \mathrm{AA}$ & & \\
\hline Talebiyan et al., 2015 & $\mathrm{TCGsY} \underline{25}+\mathrm{G} \underline{\overline{7}}$ & FAAH & $0.025 \mathrm{IU} / \mathrm{ml}$ & 66 & 27 Fast & & & & \\
\hline Yildız et al., 2015 & SMEGsY $10 \mathrm{G} \overline{5}$ & $\mathrm{LE}$ & $10 \mathrm{mM}$ & 26 & & 27 & $49 \mathrm{AA}$ & 29 & 52 \\
\hline $\begin{array}{l}\text { Panyaboriban et al., } \\
2015\end{array}$ & $\begin{array}{l}\text { TCFY15 } \overline{\mathrm{G}}^{+}+ \\
+0,5 \% \text { Equex }\end{array}$ & $\begin{array}{l}\text { Trehalose+ } \\
+ \text { Sucrose }\end{array}$ & $30 \mathrm{mM}$ & 79 & & 84 & 82 & & \\
\hline Nalley et al., 2016 & TCF & Y-Omega 3 & $20 \%$ & & & & 60 & & \\
\hline Câmara et al., 2016 & TY10G $\underline{6}$ & Catalase & & & & & & & \\
\hline Ar1 et al., 2016. & TY20G 7 & GPx & $5 \mathrm{IU} / \mathrm{ml}$ & 40 & 23 & 36 & 37 & 50 & 72 \\
\hline \multicolumn{10}{|c|}{ 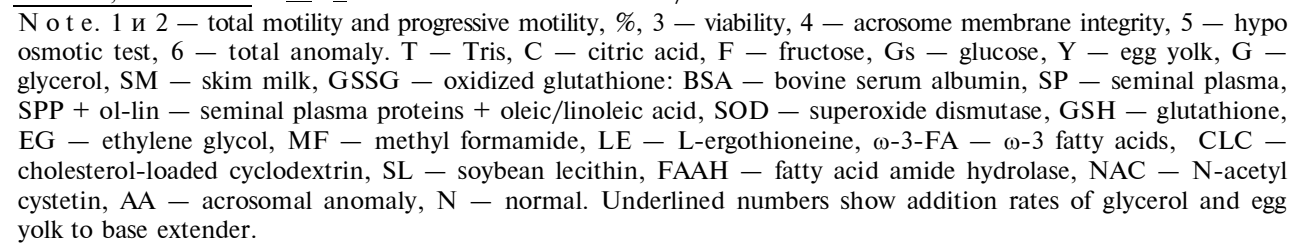 } \\
\hline
\end{tabular}

The influence of different additives on frozen-thawed sperm parameters is presented in the table. It is seen that in most of studies Tris-based exdender with egg yolk and glycerol has been used. Considering the table, it is noticed that while some of studies' results are very high, some of them are very poor. It should be not ignored that these differences may depend on the specific properties and doses of additives and kind of base extender used [46] as well as freezing method [47], type of cryoprotectant [33], glycerolisation method, glycerol ratio [48], ram individuality and season [49, 50].

Thus, in this review, we only endeavored to divulge additives that provide a good improvement in post-thaw ram semen quality because ram spermatozoa is susceptible against freezing process. In today's conditions, we believe that thorough technological advances in semen freezing techniques and analyzing systems such as assessment of kinematic parameters, determination of genet- 
ic, mitochondrial and membrane defects in sperm, the effects of additives or various supplementations on ram semen freezability will be better explored. On the other hand, as each antioxidant and supplement have different influences on post-thaw semen properties, the choice of extender additives mustn't be done randomly. Before installation of experimental design, more detailed preliminary research on the many aspects of supplement agent must be done because of the preventing detrimental effects of ram semen freezing procedure and antioxidant mechanism of additive compounds is highly complicated. Cryopreservation of ram semen is a subtle matter and needed to study deeply and multifactorial experiment designs in future. Although many investigators have made valuable efforts and obtained good laboratory results in ram semen freezing a cryopreservation method giving satisfactory fertility rates with cervical insemination has not been established yet. As a result, further studies must be carried out to explore the unknown aspects of various supplements and tested with combination of different compounds and in different doses in order to install an ideal cryopreservation template in ram semen. Furthermore, even though addition of various antioxidants, hormones and the some other substances to freezing mediums have improved freezability of ram semen in experimental conditions, these results must be confirmed in field studies. Thereby, the sperm potential fertility predicted from laboratory survey must be compared with conception or lambing rates.

\section{REFEREN C ES}

1. Quinn P.J., White I.G., Cle land K.W. Chemical and ultrastructural changes in ram spermatozoa after washing, cold shock and freezing. J. Reprod. Fertil., 1969, 18: 209-220.

2. King M.E., M c Kelvey W.A.C., D ingwall W.S., Mat thews K.P., Gebbie F.E., Mylne M.J.A., S te wart Robinson J.J. Lambing rates and litter sizes following intrauterine or cervical insemination of frozen-thawed semen with or without oxytocin administration. Theriogenology, 2004, 62: 1236-1244 (doi: 10.1016/j.theriogenology.2004.01.009).

3. Woelders H., Hi e mstra S.J. The potential of cryopreservation and reproductive technologies for animal genetic resources conservation strategies. Cryobiology, 2011, 63(3): 316-317 (doi: 10.1016/j.cryobiol.2011.09.042).

4. Rodríguez-Martínez H. Sperm biotechnologies in domestic species: state of the art. Anim. Reprod., 2013, 10(3): 268-276.

5. B a ra n A., A k K., I le ri I.K., S o y lu M.K. Effects of adding bull seminal plasma to ram semen extenders on post-thaw spermatozoa motility and morphology. Indian Vet. J., 2004, 81(7): 780-783.

6. Marti E., Marti J.I., Muino-Blanco T., Cebrian-Perez J.A. Effect of the cryopreservation process on the activity and immunolocalization of antioxidant enzymes in ram spermatozoa. J. Androl., 2008, 29: 4 (doi: 10.2164/jandrol.107.003459).

7. Le a hy T., d e G r a a f S.P. Seminal plasma and its effect on ruminant spermatozoa during processing. Reprod. Domest. Anim., 2012, 47(4): 207-213 (doi: 10.1111/j.1439-0531.2012.02077.x).

8. de Graaf S.P., Leahy T., Marti J., Evans G., Maxwe 11 W.M.C. Application of seminal plasma in sex-sorting and sperm cryopreservation. Theriogenology, 2008, 70(8): 13601363 (doi: 10.1016/j.theriogenology.2008.07.012).

9. Alvare z J.G., S t o r e y B.T. Differential incorporation of fatty acids into and peroxidative loss of fatty acids from phospholipids of human spermatozoa. Mol. Reprod. Dev., 1995, 42(3): 334-346 (doi: 10.1002/mrd.1080420311).

10. Ar 1 U.Ç., Özt ürkle r Y. Oxidative stress during long and short term storage of sperm and usage of antioxidant. Turkiye Klinikleri J. Reprod. Artif. Insemin.-Special Topics, 2015, 1(3): 16-21.

11. Öztürkle r Y., Y 11 d 1 z S., Güngör Ö., P a n c a rc 1 M., K a ça r C., Ar 1 U.Ç. The effects of L-ergothioneine and L-ascorbic acid on in vitro maturation and embryonic development in sheep oocytes. Kafkas Univ. Vet. Fak. Derg., 2010, 16: 757-763.

12. B a n s a l A.K., B i l a s p u ri G.S. Impacts of oxidative stress and antioxidants on semen functions. Veterinary Medicine International, 2011, 2011: Article ID 686137 (doi: 10.4061/2011/686137).

13. U y s a 1 O., B u c a k M.N. Effects of oxidized glutathione, bovine serum albumin, cysteine and lycopene on the quality of frozen-thawed ram semen. Acta Vet. Brno, 2007, 76(3): 383-390 (doi: 10.2754/avb200776030383).

14. Bucak M.N., A teş şah i n A., Yü ce A. Effect of anti-oxidants and oxidative stress parameters on ram semen after the freeze-thawing process. Small Ruminant Res., 2008, 75: 128134 (doi: 10.1016/j.smallrumres.2007.09.002). 
15. Anghel A., Zamfirescu S., Coprean D., Sogorescu E. The effects of cysteine, bovine serum albumin and vitamin $\mathrm{E}$ on the qualitative parameters of frozen-thawed ram semen. Annals of the Romanian Society for Cell Biology, 2009, 14(2): 97-103.

16. Ari U.Ç., Kulaksiz R., Öztürkle r Y. Freezability of Tushin ram semen extended with goat or cow milk based extenders. Reprod. Domest. Anim., 2011, 46(6): 975-979 (doi: 10.1111/j.1439-0531.2011.01769.x).

17. Ari U.Ç., Kulaksiz R., Öztürkler Y., Lehi mcioğlu N.C., Yıldız S. Effect of $\mathrm{N}$-acetylcysteine (NAC) on post-thaw semen quality of Tushin rams. Kafkas Univ. Vet. Fak. Derg., 2016., 22(6): 883-887.

18. Yıldiz S., Öztürkler Y., Ari U.Ç., Lehimcioğlu N.C., Atakişi E., Ku $1 \mathrm{aksiz} \mathrm{R}$. The effects of L-ergothioneine, N-acetylcystein and cystein on freezing of ram semen. Kafkas Univ. Vet. Fak. Derg., 2015, 21(1): 81-86.

19. Agarwal A., Gupta S., Sharma R.K. Role of oxidative stress in female reproduction. Reprod. Biol. Endocrinol., 2005, 3: 28 (doi: 10.1186/1477-7827-3-28).

20. Mai a Mda S., B i c u d o S.D., S i c h e rle C.C., Ro d e 11 o L., G a 11 e g o I.C. Lipid peroxidation and generation of hydrogen peroxide infrozen-thawed ram semen cryopreserved in extenders with antioxidants. Anim. Reprod. Sci., 2010, 122(1-2): 118-123 (doi: 10.1016/j.anireprosci.2010.08.004).

21. S i 1 v a S.V., S o a re s A.T., B a t i s t a A.M., A $1 \mathrm{~m}$ e i d a F.C., $\mathrm{N}$ u ne s J.F., P e ix o t o C.A., G u e $\mathrm{r}$ a M.M. In vitro and in vivo evaluation of ram sperm frozen in tris eggyolk and supplemented with superoxide dismutase and reduced glutathione. Reprod. Domest. Anim., 2011, 46(5): 874-881 (doi: 10.1111/j.1439-0531.2011.01758.x).

22. Ari U.Ç., Kulaks i z R., Yıldiz S., Lehimcioğlu N.C., Öztürkler Y. Effects of antioxidants in glutathione redox cycle on freezability of ram semen (Proc. $18^{\text {th }}$ Annual Conference of the ESDAR, Helsinki, Finland, 2014). Abstracts. Reprod. Domest. Anim., 2014, 49(suppl. 3): 54 (doi: 10.1111/rda.12391). Available https://www.researchgate.net/publication/278870707_Effect_of_antioxidants_in_glutathione_redox_cycle_on_freezability_of_ram_sem en. Accessed March 31, 2017.

23. S a ntiani A., Evangelista S., S e púlveda N., Risopatryn J., Villegas J., $\mathrm{S}$ á $\mathrm{n} \mathrm{c}$ h e z R. Addition of superoxide dismutase mimics during cooling process prevents oxidative stress and improves semen quality parameters in frozen/thawed ram spermatozoa. Theriogenology, 2014, 82(6): 884-889 (doi: 10.1016/j.theriogenology.2014.07.002).

24. Bucak M.N., A te şşahin A., Var 1 ş 11 Ö., Yü ce 1 A., Tekin N., Ak ça y A. The influence of trehalose, taurine, cysteamine and hyaluronan on ram semen Microscopic and oxidative stress parameters after freeze-thawing process. Theriogenology, 2007, 67(5): 1060-1067 (doi: 10.1016/j.theriogenology.2006.12.004).

25. Panyaboriban S., Suwimonteerabutr J., Phutikanit N., SwangchanUthai T., Tharasanit T., Te chaku m p h M. Effect of various combinations of sugar supplementation in the extender on frozen-thawed ram semen quality and fertility. Thai. $J$. Vet. Med., 2015, 45(2): 229-237.

26. Najafi A., Najafi M.H., Zanganeh Z., Sharafi M., Martinez-Pastor F., Adeldust $\mathrm{H}$. Cryopreservation of ram semen in extenders containing soybean lecithin as cryoprotectant and hyaluronic acid as antioxidant. Reprod. Domest. Anim., 2014, 49(6): 934-940 (doi: 10.1111/rda.12405).

27. Em a mverdi M., Zhandi M., Shahneh A.Z., Sharafi M., Akhlaghi A., Mot lagh K.M., Dadkhah F., D avachi N.D. Flow cytometric and microscopic evaluation of post-thawed ram semen cryopreserved in chemically defined home-made or commercial extenders. Animal Production Science, 2015, 55(4): 551-558 (doi: 10.1071/AN13215).

28. Mata-Campuzano M., Álvarez-Rodríguez M., Álvarez M., Tamayo-Canul J., Anel L., de Paz P., Martínez-Pastor F. Post-thawing quality and incubation resilience of cryopreserved ram spermatozoa are affected by antioxidant supplementation and choice of extender. Theriogenology, 2015, 83(4): 520-528 (doi: 10.1016/j.theriogenology.2014.10.018).

29. Üstüner B., Alçay S., Nur Z., Sağirkaya H., Soylu M.K. Effect of egg yolk and soybean lecithin on tris-based extender in post-thaw ram semen quality and in vitro fertility. Kafkas Univ. Vet. Fak. Derg., 2014, 20(3): 393-398 (doi: 10.9775/kvfd.2013.10248).

30. Forouzanfar M., Sharafi M., Hosseini S.M., Ostadhosseini S., Hajian M., Hosseini L., Abedi P., Nili N., Rahmani H.R., Nasr-Esfahani M.H. In vitro comparison of egg yolk-based and soybean lecithin-based extenders for cryopreservation of ram semen. Theriogenology, 2010, 73(4): 480-487 (doi: 10.1016/j.theriogenology.2009.10.005).

31. Towhidi A., Zeinoaldini S., Ardebili R., Davachi N.D., Nasiri A.H. Combined $\omega-$ 3 fatty acids and $\alpha$-tocopherol supplementation improved the ovine sperm cryosurvival. Iranian Journal of Biotechnology, 2013, 11(4): 238-243 (doi: 10.5812/ijb.14469).

32. Talebiyan R., Amidi F., Samini M., Mirshokraei P., Dehkordi S.H. Effect of met-anandamide on prevention of hyperactivation, cryo-capacitation and acrosome reaction in ram semen cryopreservation. Kafkas Univ. Vet. Fak. Derg., 2015, 21(4): 545-551 (doi: 10.9775/kvfd.2014.12897). 
33. da Silva E.C.B., Cajueiro J.F. de P., Silva S.V., Guerra M.M.P. Ethylene glycol and acetamide cryoprotectants on in vitro viability of thawed ram spermatozoa. Ciência Rural, 2012, 42(6): 1083-1088 (doi: 10.1590/S0103-84782012005000027).

34. Chinoy N.J. Ascorbic acid levels in mammalian tissues and its metabolic significance. Comp Biochem. Physiol. A. Comp. Physiol., 1972; 42(4): 945-952 (doi: 10.1016/0300-9629(72)90400-8).

35. B u e t t n e r G.R. The pecking order of free radicals and antioxidants: lipid peroxidation, $\alpha$-tocopherol, and ascorbate. Arch. Biochem. Biophys., 1993, 300(2): 535-543 (doi: 10.1006/abbi.1993.1074).

36. Fraga C.D., M ot chnik P.A., Shinegan a M.K., H e lbo ck H.J., J a c o b R.A., A m e s B.N. Ascorbic acid protects against oxidative DNA damage in human sperm. PNAS USA, 1991, 88(24): 11003-11006 (doi: 10.1073/pnas.88.24.11003).

37. Y $11 \mathrm{~d} 1 \mathrm{z}$ S., D a ş k $1 \mathrm{n}$ A. Koç spermasının farklı antioksidan içeren sulandırıcılarla kısa süreli saklanması. Kafkas Univ. Vet. Fak. Derg., 2004, 10(2): 155-159.

38. H a m e dan i M.A., T a h m a s b i A., $\mathrm{N}$ as e ri a $\mathrm{n}$ A., A h a n g a r i Y.J. Influence of added vitamin $\mathrm{S}$ on chilled and frozen-thawed ram sperm cryopreserved in tris extender. International Journal of Biology, Pharmacy and Allied Sciences, 2015, 4(9): 5848-5859

39. H a m e d a n i M.A., T a h m a s b i A.M., A h a n g a r i Y.J. Effects of vitamin supplementation on the quality of Ovine spermatozoa. Open Veterinary Journal, 2013, 3(2): 140-144.

40. C a i J.G., S u n S.Q., W a $n \mathrm{~g}$ L.G., G u H.J. The effect of adding vitamin $\mathrm{B}_{12}$ in sperm diluter on quality of bull's straw frozen sperm. J. Liaoning Agricult. Coll., 2004, 6: 10-11.

41. A p pasamy M., Muttukrishna S., Pizzey A.R., Ozturk O., Groom e N.P., S e r h a 1 P., J a u n i ux E. Relationship between male reproductive hormones, sperm DNA damage and markers of oxidative stress in infertility. Reproductive BioMedicine Online 22007, 14(2): 159-165 (doi: 10.1016/S1472-6483(10)60783-3).

42. B e 11 a n t i F., M a t e o M., Rollo T., d e Rosario F., Greco P., Ven$\mathrm{de} \mathrm{mi}$ a $\mathrm{le}$ G. Sex hormones modulate circulating antioxidant enzymes: impact of estrogen therapy. Redox Biology, 2013, 19(1): 340-346 (doi: 10.1016/j.redox.2013.05.003).

43. Su c cu S., B e rlinguer F., P a s c i u V., S a t t a V., Le oni G.G., Nait a n a S. Melatonin protects ram spermatozoa from cryopreservation injuries in a dose-dependent manner. Journal of Pineal Research, 2011, 50(3): 310-318 (doi: 10.1111/j.1600-079X.2010.00843.x).

44. D a s G r a ça s C.P., Li m A. in P.G., Fid e li s A.A.G., C a r d o s o J.R., B $1 \mathrm{u}$ m e H., M o n d a d o ri R.G. Metil-formamida na criopreservação de sêmen ovino [Methylformamide in ram semen cryopreservation]. Ciênc. anim. bras., 2013, 14(4): 481-487 (doi: 10.5216/cab.v14i4.17835).

45. Motamedi-Mojdehi R., Roostaei-Ali Mehr M., Rajabi-Tousta $\mathrm{n}$ i R. Effect of different levels of glycerol and cholesterol-loaded cyclodextrin on cryosurvival of ram spermatozoa. Reprod. Domest. Anim., 2014, 49(1): 65-70 (doi: 10.1111/rda.12225).

46. G i 1 J., S öd e r quis t L., R od rigue z-M a r t i n e z H. Influence of centrifugation and different extenders on post-thaw sperm quality of ram semen. Theriogeneolgy, 2000, 54(1): 93-108 (doi: 10.1016/S0093-691X(00)00328-9).

47. A n e 1 L., d e Paz P., Álvarez M., Chamorro C.A., B o ix o J.C., M a n s o A., G o n zá le z M., K a a b i M., A n e 1 E. Field and in vitro assay of three methods for freezing ram semen. Theriogenology, 2003, 60(7): 1293-1308 (doi: 10.1016/S0093-691X(03)00140-7).

48. Ö z t ü rk le r Y., A k K., I l e ri I.K. Koç spermasının yoğun gliserollü sulandırıcılarda dondurulması. Istanbul Univ. Vet. Fak. Derg., 1999, 25(2): 399.

49. Ö z t ü rk le r Y., A k K., I l e ri I.K. The effect of season on post thaw spermatological properties in Kivircik rams. Kafkas Univ. Vet. Fak. Derg., 1997, 3(1): 73-79.

50. Frazão Sobrinho M., Caste lo Branco M.A., Sous a A. Júnior, Nasci m e nto I.M.R., M ot a L.H.C.M., C a rvalho Y.N.T., F e rreira S.B., Costa D.N.M., M o raes F.J. Júnior, S o uza J.A.T. Características do sêmen de carneiros Dorper, Santa Inês e sem padrão racial definido, pré e pós-congelação, nos períodos chuvoso e seco [Characteristics of the semen of Dorper, Santa Ines and undefined breed sheep, pre- and post-freezing, in the rainy and dry period]. Arq. Bras. Med. Vet. Zootec., 2014, 66(4): 969-976 (doi: $10.1590 / 1678-6465)$. 